\title{
Worker piping associated with foraging in undisturbed queenright colonies of honey bees
}

\author{
SC Pratt, S Kühnholz, TD Seeley, A Weidenmüller \\ Section of Neurobiology and Behavior, Cornell University, Ithaca, NY 14853, USA
}

(Received 11 January 1995; accepted 9 November 1995)

\begin{abstract}
Summary - Worker piping, previously reported only in association with colony disturbance or queenlessness, was seen in undisturbed, queenright colonies. Workers piped by pressing the thorax to the comb, spreading the wings slightly and lifting the abdomen towards the wings, which vibrated noticeably as the bee emitted an audible wail. Pipers wandered throughout the hive for up to $2.5 \mathrm{~h}$, stopping every few seconds to emit a pipe, which lasted about $1 \mathrm{~s}$. The sound showed little frequency modulation, and a fundamental frequency of $330-430 \mathrm{~Hz}$. It appeared to be produced by wing muscle vibrations and to be loaded into the comb by pressing down the thorax. Of three workers whose experiences prior to piping were known, two had been foraging and one had been unloading water collectors. Piping in this context may serve as a foraging-related signal, although its receivers and the information it transmits remain unknown.
\end{abstract}

worker bee / acoustic communication / foraging / piping

\section{INTRODUCTION}

Honey bees coordinate their social behavior through an impressive array of specialized signals, many of which incorporate air- or substrate-borne vibrations generated by the wing muscles. These include the waggle dance (Michelsen et al, 1986a), the PiepLaut or stop signal (Esch, 1964; Nieh, 1993; Kirchner, 1993), queen piping (Michelsen et al, 1986b) and the beeps and buzz runs which precede swarm departure (Esch, 1964, 1967).
Worker piping is another wing-musclebased acoustic behavior which presumably serves as a signal, but whose significance remains unknown. It was first described by Armbruster (1922) and named for its similarity to the piping of queens. Subsequent descriptions by Örösi-Pál (1932) and Ohtani and Kamada (1980) detailed the posture assumed by a piping worker: she presses her thorax to the comb, lifts her abdomen, raises her wings and spreads them slightly (making an angle of about $40^{\circ}$ ), and vibrates her wings to emit a loud beep. The worker 
repeats this behavior at a rate of 1-6 pipes per minutes, each pipe lasting $0.4-1.0$ second (Örösi-Pál, 1932; Wenner, 1964; Ohtani and Kamada, 1980). Ohtani and Kamada (1980) described two distinct forms of worker piping: a low frequency sound (fundamental $=350 \mathrm{~Hz}$ ) associated with worker egg-laying in hopelessly queenless nests, and a higher frequency sound (fundamental = $500-700 \mathrm{~Hz}$ ) performed by guard bees at the nest entrance during attacks by predatory wasps. Wenner (1964) also reported that piping is associated with disturbance of the hive by intruders or by jarring and found a fundamental frequency of approximately $500 \mathrm{~Hz}$.

Here we report worker piping resembling previous descriptions in acoustic characteristics and in behavioral appearance, but associated with foraging in undisturbed, queenright colonies.

\section{METHODS}

\section{Study sites}

Sound recordings and behavioral observations were made at the Archbold Biological Station near Lake Placid, Florida in January 1994, at the Cranberry Lake Biological Station in the Adirondack Park in northern New York State in June 1994, and at Liddell Laboratory near ithaca, NY in September 1994.

\section{Bees and observation hives}

Colonies of 4 000-6 000 bees (Apis mellifera ligustica) were housed in two- or three-frame observation hives (internal dimensions $46.0 \mathrm{x}$ $50.0 \times 4.5 \mathrm{~cm}$ or $46.0 \times 70.5 \times 4.5 \mathrm{~cm}$ ). The glass wall on one face of the bottom frame of each hive was replaced by a wooden or plexiglass frame covered with black nylon screening (tulle, openings $3 \mathrm{~mm}$ in diameter). This allowed sounds produced by the bees to be heard and recorded. The hives were sheltered either in a portable hut
(Cranberry Lake) or in the bee labs at Archbold Biological Station and Liddell Laboratory. Each hive had a single entrance allowing foragers free access to the surrounding countryside.

\section{Sound recording and analysis}

We used a particle velocity-sensitive microphone (modification of the design by Bennet-Clark, 1984) held $\sim 4 \mathrm{~cm}$ above a piping bee. The frequency response of this microphone was flat within $1.5 \mathrm{~dB}$ from $30-3000 \mathrm{~Hz}$ and within $3 \mathrm{~dB}$ from 20-6 000 $\mathrm{Hz}$. Sounds were recorded with a Marantz PMD 221 cassette recorder (flat within $1.5 \mathrm{~dB}$ from 40-12 $000 \mathrm{~Hz}$ ). Sonagrams were produced with a Kay DSP Sona-Graph Model 5500. Oscillograms and power spectra were produced with SoundEdit and Canary, after the recordings had been digitized at a sampling rate of $22 \mathrm{kHz}$ with a MacRecorder and an Apple Macintosh Ilci computer.

\section{RESULTS}

\section{Behavioral description}

Piping was first detected as a train of loud plaintive sounds reminiscent of the bleating of sheep. Careful searching of the comb region in which the sound originated revealed a worker performing a striking and stereotyped behavior coincident with each sound: she stood still, pressed her thorax to the substrate, spread her wings slightly and lifted her abdomen towards her wings, which vibrated noticeably during sound emission. Usually the bee pressed her thorax to the comb while piping, but sometimes she pressed it against another worker, the glass wall of the hive, or the wooden frame around the comb.

Of the several pipers observed, three were followed for more than a few minutes and indicated the remarkable duration of the behavior. One bee, observed on 29 June 1994 , piped steadily for over $1 \mathrm{~h}$ and pro- 
duced occasional pipes $2.5 \mathrm{~h}$ after her first one. Another, observed on 7 January 1994 (in Florida), was detected after piping for an unknown length of time, and continued piping for $2 \mathrm{~h}$. The third bee, observed on 27 July 1994 showed less perseverance, piping for only $9 \mathrm{~min}$, although she was followed for only 4 min after cessation and may have later resumed piping. All the bees walked slowly on a circuitous path extending throughout the hive (fig 1), stopping every few seconds to pipe. We rarely heard more than two pipers at the same time, and casual inspection of an observation hive usually revealed none at all. On 20 July 1994, however, at least three pipers were active. This was at the end of a day of good weather and active foraging, during which the colony had experienced an extremely large nectar influx after nine days of very low nectar intake (Seeley, unpublished data).

The volume of a pipe depended on the surface on which the bee was standing, with glass and wood substrates generating the loudest sounds. This observation, as well as the pressing down of the thorax and the visible motion of the wings during sound production, suggests that bees generate the vibrations with their wing muscles and load them into the substrate, which normally is a comb. The airborne vibrations may therefore have included radiation of sound from substrate to air, as well as direct sound emission from the bee. Surrounding bees may have perceived the sound through either its airborne or its substrate-borne components, but no apparent behavioral response to piping was ever observed.

\section{Sound analysis}

A 144 s recording of a single bee contained 41 pipes, with an average duration of $1.0 \pm$ $0.43 \mathrm{~s}$ (mean $\pm \mathrm{SD}$ ) and an average interpipe interval of $2.4 \pm 1.0 \mathrm{~s}(n=40$; one pipe
Fig 1. Path of a piping bee observed for $30 \mathrm{~min}$ on 29 June 1994. Each dot indicates a site at which the bee stopped walking and piped. The dashed line indicates a period in which the observer briefly lost sight of the bee.

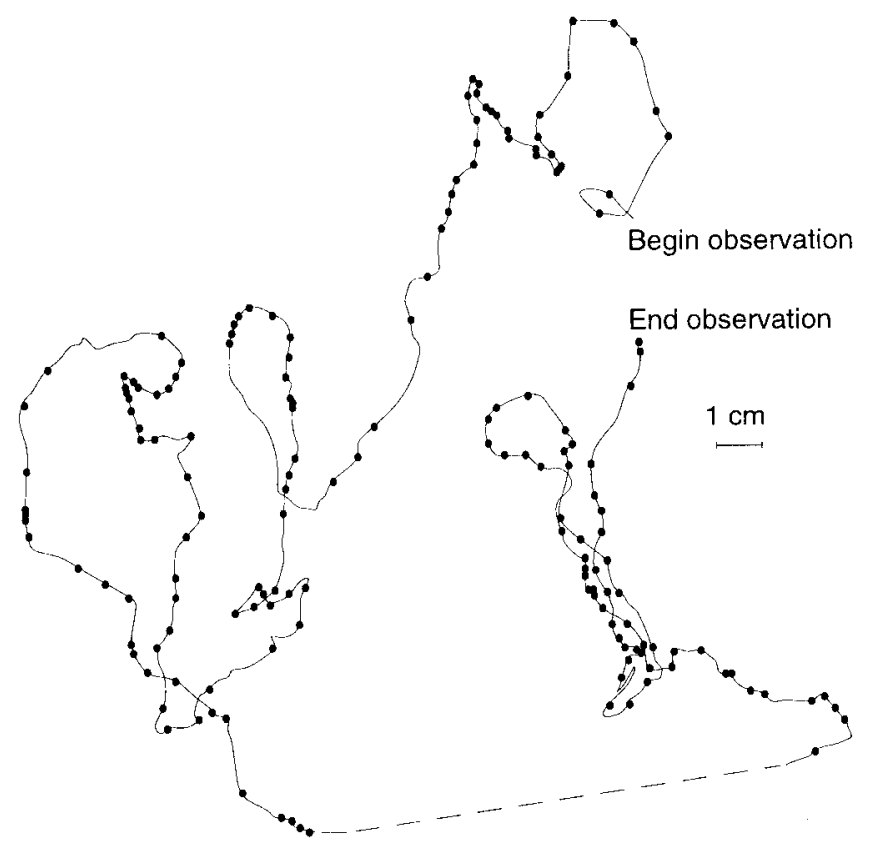


was obstructed by noise). Interpipe intervals were measured from the end of one pipe to the beginning of the next. Pipes ranged in duration from $0.15-2.2 \mathrm{~s}$. Each pipe consisted of a single long pulse, showing little frequency modulation (figs $2 \mathrm{~A}, 2 \mathrm{~B}$ ). The harmonic nature of the sound is evident in an expanded view of the pulse (fig 2C). Power spectra of 17 pipes by this bee showed a strong peak at $337 \pm 15 \mathrm{~Hz}$ (fig 3), similar to the fundamental frequencies of other wing-muscle-generated sounds (Michelsen et al, 1986a, 1986b). Smaller peaks at the higher harmonics were also present, as well as a significant amount of energy between 2500 and $5500 \mathrm{~Hz}$. Analysis of six pipes by a second bee in a different colony yielded similar results, although the fundamental frequency was higher $(424 \pm 16 \mathrm{~Hz})$ and the pipe duration shorter $(0.29 \pm 0.02 \mathrm{~s})$.

\section{Identity of pipers}

The first piper followed carefully (the same one used for sound analysis) was recognizable as a forager by the traces of pollen on her pollen baskets. She piped for over $2 \mathrm{~h}$ during the afternoon of a warm and sunny day. The colony was collecting $1.75 \mathrm{M}$ sucrose solution from several large feeders near the hive entrance, as well as significant amounts of pollen from natural sources. The piper was marked and her behavior over the next few days noted. Although she

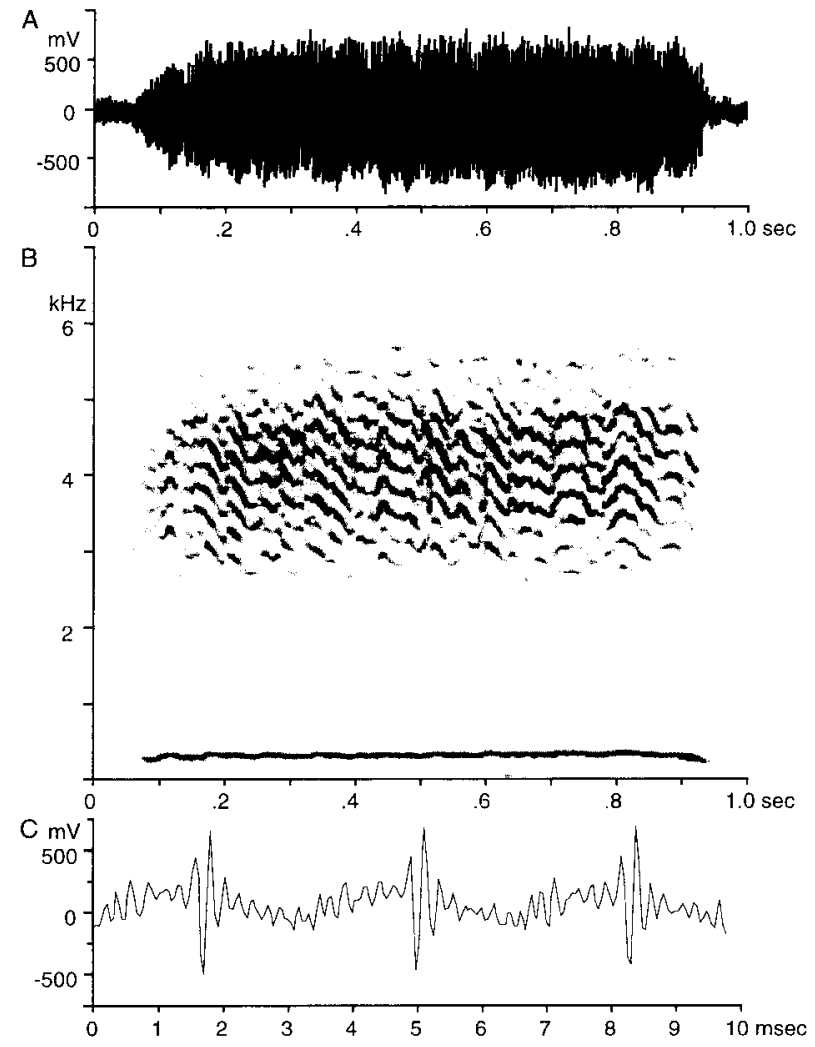

Fig 2. A. Oscillogram of a single pipe. B. Sonagram of A. C. Expanded view of $A$. 
Fig 3. Power spectrum (relative to maximum) of the pipe shown in figure 2.

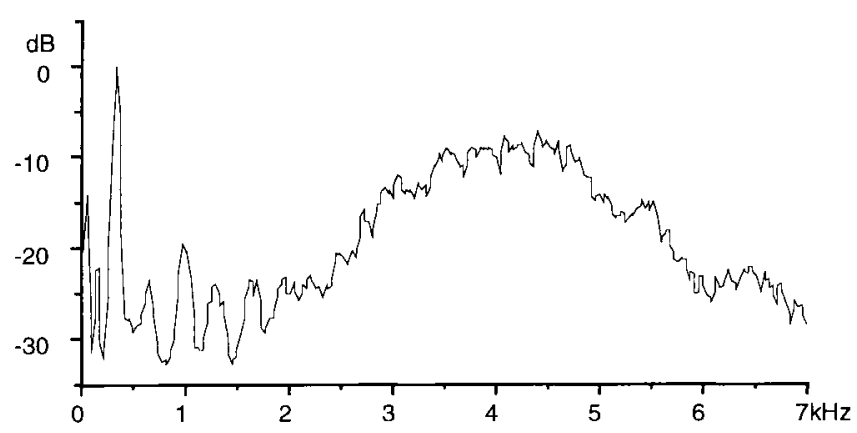

was not seen piping again, two days later she was found foraging for nectar at the feeders, and she continued to do so for at least the next two days.

Another bee had been individually labeled and identified as a water collector during the morning, but the approach of a thunderstorm had reduced her collection efforts by early afternoon. She began piping 20 min after her last departure from the hive, and continued for at least $2.5 \mathrm{~h}$. The colony had experienced artificial heating of its brood comb during the morning and early afternoon, as part of a study of the regulation of water collection.

A third bee had received water from a water forager $12 \mathrm{~min}$ before beginning to pipe, and had been engaged in tonguelashing, a behavior associated with evaporative cooling of the hive. These observations were also made during artificial heating of the hive (Kühnholz and Seeley, unpublished data).

\section{DISCUSSION}

More than 70 years after its first description, the function of worker piping remains mysterious. Ohtani and Kamada (1980) suggested that queen and worker piping serve similar functions, and compared high and low frequency worker piping with tooting and quacking respectively; targets of aggres- sion (virgin queens not yet emerged from their cells and egg-laying workers) produce quacks or low frequency worker pipes, whereas aggressive bees (freely moving virgin queens and guards) produce toots or high frequency worker pipes. Closer comparison, however, reveals clear distinctions between queen and worker piping. Toots and quacks last several seconds and are broken up into syllables (Michelsen et al, 1986b) whereas worker pipes last no more than one second and consist of a single pulse of sound. Moreover, queens pipe only in the context of colony reproduction, while workers pipe in a variety of circumstances, including foraging and colony defense in both queenless and queenright colonies. Given these differences, it may be misleading to infer the role of worker piping from the functions of queen piping.

The context in which piping occurs may better indicate its function. In contrast to previous reports, we found it was associated with foraging in queenright colonies, rather than with colony disturbance or worker aggression in queenless colonies. Of three bees whose experience immediately prior to piping was known, one was a pollen collector, one was a water collector, and one was a water receiver. In one case bad weather had recently cut off water collection and the colony was experiencing a stressful heating of the brood comb. While this suggests a signal of deteriorating or unsafe foraging conditions, excessive hive 
temperature, or other dangerous hive conditions, many other cases of piping were accompanied by good weather and active foraging. Indeed, the only case in which more than one or two pipers were active occurred on a day of exceptionally high nectar intake.

The behavior described here and that reported by previous authors may serve distinct functions, mediated either by subtle variation in the signal itself, or by contextdependence in the bees' response to the same signal. Our observations differ in some respects from earlier descriptions; we did not see the excited running of workers in between pipes reported by Örösi-Pál (1932) and Ohtani and Kamada (1980), or the strong first and second harmonics in the sonagrams of Ohtani and Kamada (1980) and Wenner (1964). In addition, we found a much higher rate of piping (17 pipes/min) than that indicated by Ohtani and Kamada (1980) and Orösi-Pál (1932).

Whatever its function, the form of piping suggests that it is a signal transmitted as substrate vibration. Because piping workers apparently load the signals into the substrate by pressing their thoraxes to the comb, surrounding bees may be able to perceive them via the subgenual organs located in their legs (Autrum and Schneider, 1948). Clear evidence for this means of transmission, however, will require direct measurements of comb vibration during piping. If pipes are transmitted primarily through the substrate, airborne recordings must be interpreted cautiously. In particular, the transmission of comb vibrations into the air may disproportionately accentuate higher frequencies (Michelsen et al, 1986b). In the case of queen piping, Michelsen et al (1986b) suggested that frequencies above the $200-550 \mathrm{~Hz}$ fundamental are unimportant in signal transmission, because they propagate relatively poorly through the comb. Since worker piping resembles queen piping in frequency composition and method of loading into the comb, its higher frequency components may be similarly unimportant.

Comparison with queen piping also allows a rough estimate of the signal's range. Michelsen et al (1986b) calculated that the fundamental, at the amplitudes typical of queen piping, will remain at levels above the response threshold of workers for approximately $10 \mathrm{~cm}$. Although we did not measure sound amplitudes, worker piping is subjectively similar in volume to queen piping. Thus, this $10 \mathrm{~cm}$ range may also apply to worker piping. If so, a single worker wandering throughout the hive and piping repeatedly for several hours could communicate with virtually the entire colony.

Further studies of worker piping should focus on the colony and environmental conditions correlated with piping, and on context-dependent variation in the form of piping. The identity of the signal's receivers and the effect of the signal on their behavior should also be examined. Uncovering the function of this behavior will contribute to a comprehensive understanding of acoustic communication in honey bees, the diversity of which has only begun to be adequately described and analyzed.

\section{ACKNOWLEDGMENTS}

We are indebted to T Forrest for a critical reading of the manuscript, to $U$ Grafe for the loan of recordings equipment and to $D$ Rich for invaluable assistance in building the microphone. This work was supported by the US National Science Foundation (IBN-9221150) and the Department of Agriculture (Hatch grant NY(C)-191407).

\section{Résumé - Le chant des ouvrières asso- cié au butinage dans des colonies d'abeilles non perturbées et possédant une reine. Le chant des ouvrières, déjà mentionné mais seulement en association avec une perturbation de la colonie ou une absence de reine, a été observé dans des}


colonies non perturbées et possédant une reine. Lorsqu'elles chantent, les ouvrières pressent leur thorax sur le rayon, déploient légèrement leurs ailes et relèvent l'abdomen vers les ailes. On voit celles-ci vibrer nettement quand l'abeille émet un son audible. Les chanteuses peuvent circuler dans la ruche pendant 2 heures et demie en s'arrêtant à quelques secondes d'intervalle pour émettre un chant qui dure environ 1 seconde (fig 1). Ce comportement est peu fréquent ; il est rare de trouver deux chanteuses actives en même temps et l'inspection fortuite d'une ruche d'observation n'en révèle en général aucune. La pression du thorax et le mouvement visible des ailes pendant la production de son laissent penser que les abeilles produisent les vibrations avec leurs muscles alaires et les font passer dans le rayon. Les autres abeilles peuvent percevoir le chant à l'aide de leur organe subgénual. Chaque chant est constitué d'un son continu de faible modulation de fréquence, d'une fréquence de base comprise entre 330 et $430 \mathrm{~Hz}$ et d'une énergie considérable comprise entre 3000 et $5500 \mathrm{~Hz}$ (figs 2 et 3). Sur trois ouvrières dont on connaissait l'activité avant le chant, deux avaient été butineuses et la troisième avait déchargé des collecteuses d'eau. Chanter dans ce contexte peut constituer un signal lié au butinage, bien que les destinataires et l'information transmise restent inconnues.

\section{communication sonore / butinage / chant / ouvrière}

\section{Zusammenfassung - Das Tüten von Arbeiterinnen im Zusammenhang mit Trachtverhältnissen in ungestörten wei- selrichtigen Völkern der Honigbiene (Apis mellifera L). Das Tüten von Arbeite- rinnen wurde bisher nur bei gestörten oder weisellosen Völkern beschrieben. Jetzt wurde dieses Tüten auch in ungestörten, weiselrichtigen Völkern beobachtet.}

Während des Tütens pressen die Arbeiterinnen ihren Thorax auf die Wabe, spreizen ihre Flügel leicht ab und heben ihren Hinterleib in Richtung Flügel an. Die Bienen geben dabei einen hörbaren wimmernden Ton von sich, während die Flügel sichtbar vibrieren. Diese 'Tüter' wanderten bis zu 2,5 Stunden lang durch das Volk. Alle paar Sekunden blieben sie stehen und tüteten etwa $1 \mathrm{~s}$ lang (Abb 1). Dieses Verhalten war relativ selten und nur vereinzelt waren mehr als zwei Tüter zur gleichen Zeit aktiv. Bei nur gelegentlicher Inspektion des Beobachtungsstocks entgeht es der Beobachtung. Das Herunterpressen des Thorax und die sichtbare Bewegung der Flügel während der Schallerzeugung legt nahe, daß die Bienen die Vibrationen mit ihren Flügelmuskeln erzeugen und auf die Wabe übertragen. Andere Bienen könnten dieses Tüten über ihre Subgenualorgane wahrnehmen. Jedes Tüten besteht aus einem durchgehenden Ton mit wenig Frequenzänderungen, einer Grundfrequenz von $330-430 \mathrm{~Hz}$, und beachtlicher Energie zwischen 3000 und $5500 \mathrm{~Hz}$ (Abb 2, 3). Von drei Bienen, deren Verhalten vor dem Tüten bekannt ware, kehrten zwei von Trachtflügen zurück und eine hatte Wasserholern die Ladung abgenommen. In diesem Zusammenhang könnte Tüten als trachtbezogenes Signal dienen, obwohl die Signalempfänger und die Information, die übertragen wird, noch unbekannt bleiben.

\section{Honigbiene / Kommunikation / Akustik / Tracht / Signal}

\section{REFERENCES}

Armbruster $L$ (1922) Über Bienentöne, Bienensprache und Bienengehör. Arch Bienenk 4, 221-259

Autrum H, Schneider W (1948) Vergleichende Untersuchungen über den Erschütterungssinn der Insekten. $Z$ Vergl Physiol 31, 77-88

Bennet-Clark HC (1984) A particle velocity microphone for the song of small insects and other acoustic measurements. J Exp Biol 108, 459-463 
Esch H (1964) Beiträge zum Problem der Entfernungsweisung in den Schwänzeltänzen der Honigbiene. Z Vergl Physio/ 48, 534-546

Esch $H$ (1967) The sounds produced by swarming honey bees. $Z$ Vergl Physiol 56, 408-411

Kirchner WH (1993) Vibrational signals in the tremble dance of the honeybee, Apis mellifera. Behav Ecol Sociobiol 33, 169-172

Michelsen A, Kirchner WH, Lindauer M (1986a) Sound and vibrational signals in the dance language of the honeybee, Apis mellifera. Behav Ecol Sociobiol 18 , 207-212

Michelsen A, Kirchner WH, Andersen BB, Lindauer M (1986b) The tooting and quacking vibration signals of honeybee queens: a quantitative analysis. J Comp Physiol 158, 605-611

Nieh JC (1993) The stop signal of honey bees: reconsidering its message. Behav Ecol Sociobio/ 33, 51 56

Ohtani T, Kamada T (1980) 'Worker piping': the piping sounds produced by laying and guarding worker honeybees. J Apic Res 19, 154-163

Örösi-Pál Z (1932) Wie tütet die Arbeitsbiene? Zool Anz $98,147-148$

Simpson J (1964) The mechanism of honey-bee queen piping. $Z$ Vergl Physio/ 48, 277-282

Wenner AM (1964) Sound communication in honeybees. Sci Am 210, 116-124 